\title{
Rituals, ceremonies and customs related to sacred trees with a special reference to the Middle East Amots Dafni
}

Address: Institute of Evolution, Haifa University, Haifa 31905, Israel

Email: Amots Dafni - adafni@research.haifa.ac.il

Published: 9 July 2007

Journal of Ethnobiology and Ethnomedicine 2007, 3:28 doi:10.1186/1746-4269-3-28

This article is available from: http://www.ethnobiomed.com/content/3/1/28

Dafni; licensee BioMed Central Ltd.

This is an Open Access article distributed under the terms of the Creative Commons Attribution License (http://creativecommons.org/licenses/by/2.0), which permits unrestricted use, distribution, and reproduction in any medium, provided the original work is properly cited.

\begin{abstract}
Tree worship is very common worldwide. This field study surveys the ceremonies and customs related to sacred trees in present-day Israel; it includes the results of interviews with 98 informants in thirty-one Arab, Bedouin, and Druze villages in the Galilee.
\end{abstract}

The main results are:

I. Sacred trees were treated as another kind of sacred entity with all their metaphysical as well as physical manifestations.

2. There is not even one ceremony or custom that is peculiar only to a sacred tree and is not performed in other sacred places (such as a saint's grave or a mosque).

3. Few customs, such as: quarrel settling (= Sulkha), leaving objects to absorb the divine blessing and leaving objects for charity) seem to be characteristic of this region, only.

4. In modern times, sacred trees were never recorded, in Israel, as centres for official religious ceremonies including sacrifices, nor as places for the performing of rites of passage.

5. There is some variation among the different ethnic groups: Kissing trees and worshipping them is more common among the Druze although carrying out burials under the tree, leaving water and rain-making ceremonies under them have not been recorded in this group. Passing judgments under the tree is more typical of the Bedouin in which the sacred trees were commonly used as a public social centre.

Most of the customs surveyed here are known from other parts of the world. The differences between Muslims and Druze are related to the latter's belief in the transmigration of souls.

\section{Background}

On the subject of sacred places, Turner [[1]:24] states: "This place where other realms are meet is also indicated by various forms representing a link or connection between the human and transhuman spheres, and usually set in a vertical dimension as a ladder, poles and pillars, trees and hills". Sacred places are found all over the globe and may consist of various artificial objects (buildings, shrines, graves) as well as natural ones (mountains, water source and trees).

According to Eliade [[2]:26] "Every sacred space implies a hierophany, an irruption of the sacred that results in detaching a territory from the surrounding cosmic milieu 
and making it quantitatively different". The distinction between the profane and the sacred may contain the following elements: reverence; deference; sanctions, prohibitions and rules of conduct; demands for offerings; territorial demarcation that serve as centres of pilgrimage [[3]:15,52; [2]:29-36; [4]:368; [5]:15; [6]:11,13; [7]:1]. These means were evolved to keep the profane apart from the sacred [[3]: passim; [6]:11; [8]:20-22]. One should bear in mind that the sacred cannot exist without the profane, for the former needs to be constructed and protected from the latter [[9]:50]. Trees are very common as sacred objects as and as leading landmarks of sacred places [[10]: passim; [11]: passim; [12]: passim; [13]: passim; [14]: passim; [15]: passim].

In the Muslim world, as well as in the Middle East, sacred places are closely related to the veneration of saints [[16]: passim; [17]: passim; [18]:passim; [19]:passim; [20]: passim] and, in many instances, sacred trees are connected with sacred graves/shrines and share the same supernatural powers, to grant divine blessings, to cure and to punish the offenders against the saint to whom the tree is dedicated and who endows them with their miraculous powers [[19]: passim; [15] passim; [21]:passim; [22]passim]. So it is not surprising that many of the customs and ceremonies which are performed, in general, in sacred places, are performed also at the sites of sacred trees. Frese and Gray [[23]:32] have already stated, "Sacred trees have a ritual significance. The trees and their meanings may be incorporated into rituals of curing, initiation, marriage and death. Trees used in any of these contexts stand for the divine and represent the sacred beliefs being honored through the ritual". Eliade [(1963,[4]:268] has already stated : "No tree was ever adored for itself only, but always for what was revealed through it, for what it implied and signified". Sacred trees are, thus, treated as any other sacred places and one may expect to see common customs related to sacred trees as well as to any other sacred places.

This work studies the present-day rituals and customs related to sacred trees in Israel; it is based on personal interviews as well as a field survey. Some of the customs related to sacred trees have already been considered elsewhere (seeking for asylum, taking oath, deposition of properties [[22]: passim]; tying rags [[21]: passim] and the hammering of nails [[24]:7]. Although the division is somewhat artificial, the present paper is more concerned with social as well as religious issues. It also includes some very brief additions to the former papers resulting from our continuous field study since 2000 .

\section{Methodology}

The field study (1999-2006) centred on thirty-one Arab, Bedouin, and Druze villages in the Galilee. Informants were asked about the customs and ceremonies performed near or under sacred trees. The survey covered 98 informants, consisting of 34 Druze and 64 Muslims (45 Arabs and 29 Bedouin). The distinction between "Arabs" and "Bedouin" has been made in an attempt to examine whether there were any different traditions regarding sacred trees which may reflect the different origin of nomads versus settled village people. We took "Arabs" to be people settled in their villages for several centuries, and "Bedouin" as people who originated in the deserts of Israel and Jordan, and who migrated to the Galilee in the last three centuries, and were nomads until the end of the $20^{\text {th }}$ century [[25]:30].

The Druze are an eastern Mediterranean religious group first established in Egypt in the 11 $11^{\text {th }}$ century [[26]:3]. Today they are concentrated in Lebanon, Syria, and Israel [[26]:8-14]; their belief in the revelation of God in the form of a human being is considered the most important fundamental principle of the Druze faith [[26]:15] which is not a ritual and ceremonial belief in essence, but rather a neo-platonic philosophy [[26]:17].

The survey excluded Christians, who hardly believed in sacred trees while, in the Jewish sector, the adoration/worshipping of trees is a new trend of the last two decades and almost all the worshipperd trees are already known as old Muslim sacred ones in the vicinity of graves of supposed historical righteous Jewish personalities.

In each village we carried out a preliminary survey to locate the more knowledgeable people in advance, and we also chose important religious leaders to examine their attitudes to the veneration of sacred trees. The informants were chosen mainly according to their knowledge of common/local traditions and/or religious status. The average age of the informants was $57.7(+/-14.8)$ years. Respondents were 86 males and 22 females (in general women are reluctant to be interviewed and, when they agreed the interview was held in the presence of other family members). Because of the refusal of most of the informants to be videotaped or recorded, the study is based entirely on oral interviews and field notes taken on the spot. The interviewees were asked what are the customs and manners performed at the sacred tree. We also surveyed 26 sacred trees near which active worship takes place today and could be observed. (Numbers printed in bold in the table and the text indicates how many informants related to a specific issue).

\section{Results}

The results concerning religious and community issues are presented in Table 1 family/personal issues and respect of the tree in Table 2. 
Table I: Religious/Community Issues

\begin{tabular}{|c|c|c|c|c|c|c|}
\hline Issue & $\begin{array}{l}\text { Druze } \\
(n=34)\end{array}$ & $\begin{array}{l}\text { Bedouin } \\
(n=29)\end{array}$ & $\begin{array}{l}\text { Arab } \\
(n=45)\end{array}$ & $\begin{array}{l}\text { Field observ } \\
\text { ations } \\
(n=26)\end{array}$ & $\begin{array}{l}\text { References } \\
\text { from the Middle } \\
\text { East \& adjacent } \\
\text { areas }\end{array}$ & $\begin{array}{l}\text { References } \\
\text { from other } \\
\text { Countries }\end{array}$ \\
\hline $\begin{array}{l}\text { Religious/social/ } \\
\text { leaders \& meetings }\end{array}$ & 23.5 & 31.0 & 26.6 & 0 & & 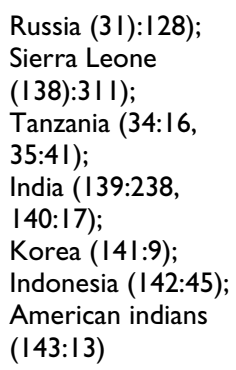 \\
\hline $\begin{array}{l}\text { Animal sacrifice } \\
\text { (when vows come } \\
\text { through) }\end{array}$ & 50 & 48.2 & 42.2 & 7.6 & $\begin{array}{l}\text { Lebanon } \\
\text { (144:334); } \\
\text { Syria (145:290) }\end{array}$ & India (40:344) \\
\hline $\begin{array}{l}\text { Pilgrimage/Zayara/ } \\
\text { family gatherings }\end{array}$ & II & 13.8 & 13.3 & 23.0 & Israel (146:1|3) & \\
\hline $\begin{array}{l}\text { Rain-making } \\
\text { ceremonies }\end{array}$ & 0 & 27.5 & 15.5 & 0 & $\begin{array}{l}\text { Arabia }(62:|1-| 2) ; \\
\text { Algeria }(147: 4 \mid) ; \\
\text { Tunisia } \\
\text { (54:52I,519; } \\
\text { 147:242): }\end{array}$ & $\begin{array}{l}\text { Ancient Rome (I2: } \\
\text { I:232); } \\
\text { Tanzania } \\
\text { (34:16,37,4I); } \\
\text { Kenya } \\
\text { (148:I43,I45; } \\
\text { 47:I39-I40); } \\
\text { Sudan (29:464); } \\
\text { Uganda (I49:38; } \\
\text { 48: passim); } \\
\text { East Africa } \\
\text { (150:263); } \\
\text { Tanzania (52:476- } \\
\text { 477); } \\
\text { Zimbabwe, (I25:6; } \\
\text { I5I:379; 46:362; } \\
358,361 ; \\
\text { I52:29I); } \\
\text { Ruanda } \\
\text { (153:82,86); } \\
\text { Chad (57:229- } \\
\text { 235); } \\
\text { Senegal (35:420); } \\
\text { Mozambique } \\
\text { (I22:237); } \\
\text { Centra Africa } \\
\text { (49:53-55) India } \\
\text { (40:330; 5I:67; } \\
\text { Papua } \\
\text { (53:386,387) }\end{array}$ \\
\hline $\begin{array}{l}\text { Passing judgment } \\
\text { under the tree }\end{array}$ & 0 & 27.5 & 4.4 & 0 & $\begin{array}{l}\text { Ancient Israelites } \\
\text { (Judges, 4:5) }\end{array}$ & $\begin{array}{l}\text { Germany (I54:85); } \\
\text { Morocco, France, } \\
\text { Switzerland } \\
\text { (I4:I45); } \\
\text { Somalia (I55:169); } \\
\text { India (27:59); } \\
\text { Japan (I56:28) }\end{array}$ \\
\hline
\end{tabular}


Table I: Religious/Community Issues (Continued)

\begin{tabular}{|c|c|c|c|c|c|c|}
\hline $\begin{array}{l}\text { Sulkha } \\
\text { (conciliation of } \\
\text { quarrels) under } \\
\text { the tree }\end{array}$ & 0 & 20.6 & 0 & 0 & & \\
\hline $\begin{array}{l}\text { Leaving water } \\
\text { under the tree }\end{array}$ & 0 & 13.8 & 8.9 & 23.0 & $\begin{array}{l}\text { Kurdistan } \\
(157: 384)\end{array}$ & $\begin{array}{l}\text { Scotland } \\
\text { (99:75,76); } \\
\text { Russia (106:322); } \\
\text { India (II5:20, } \\
\text { personal } \\
\text { observation. } \\
\text { I0.2.07); }\end{array}$ \\
\hline
\end{tabular}

\begin{tabular}{lllll}
\hline $\begin{array}{l}\text { Decoration of tree } \\
\text { (leader's pictures) }\end{array}$ & $\mathbf{1 4 . 7}$ & 0 & 0 & 7.6 \\
\hline $\begin{array}{l}\text { Official religious } \\
\text { ceremconies } \\
\text { under the tree } \\
\text { and/or grove }\end{array}$ & 0 & 0 & 0 & 0 \\
\hline
\end{tabular}

\section{6}

Ancient Greece
$(158: 219$ note
$417) ;$
Guinea - Bissau
$($ I59:389);
Siera Leone
(139:3II);
Zimbabwe (61:6);
Liberia (160:1222);
Mozambique,
(I22:9);
Inner Mongolia
(I29:283);
Okinawa
$(161: 48,49)$

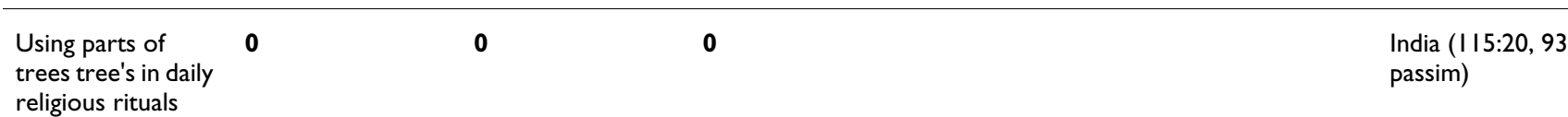

\section{Sacrifice to}

appease

supernatural

beings

\begin{tabular}{|c|c|}
\hline $\begin{array}{l}\text { Biblical times } \\
\text { Hosea }(4: 13)\end{array}$ & $\begin{array}{l}\text { Ancient Crete } \\
\text { (I62:I 28); } \\
\text { Ancient Greece } \\
\text { (I63:74; I I58:220); } \\
\text { Russia (3I:94; } \\
\text { I06:32I, I64:I I4); } \\
\text { Siberia (I65:853); } \\
\text { Inner Mongolia } \\
\text { (I29:28I); } \\
\text { Ghana (I66:69); } \\
\text { Liberia (I60:I222); } \\
\text { Nigeria (I67:425); } \\
\text { East Africa } \\
\text { (I68:52, I I48:263); } \\
\text { Kenya (I69:I55); } \\
\text { Liberia (I60:I222); } \\
\text { India (I70:294); }\end{array}$ \\
\hline & $\begin{array}{l}\text { East Africa (45:4; } \\
\text { I7I:57); } \\
\text { Kenya (I69: } \\
\text { passim); } \\
\text { Liberia (I60:1222); } \\
\text { Sierra Leone (172: } \\
\text { I59,160); } \\
\text { West Africa: } \\
\text { (173:63); } \\
\text { India (76:9I, } \\
\text { I74:50; Nigeria } \\
\text { (175:80,81); }\end{array}$ \\
\hline
\end{tabular}

Performing rites of $\mathbf{0}$

passage
0

0 
Table 2: Family/Personal Issues/Respect of the tree

\begin{tabular}{|c|c|c|c|c|c|c|}
\hline Issue & $\begin{array}{l}\text { Druze } \\
(n=34)\end{array}$ & $\begin{array}{l}\text { Bedouin } \\
(n=29)\end{array}$ & $\begin{array}{l}\text { Arab } \\
(n=45)\end{array}$ & $\begin{array}{l}\text { Field obser- } \\
\text { vations } \\
(n=26)\end{array}$ & $\begin{array}{l}\text { References } \\
\text { from the Middle } \\
\text { East and } \\
\text { adjacent regions }\end{array}$ & $\begin{array}{l}\text { World } \\
\text { references }\end{array}$ \\
\hline Rag tying & 73.5 & 68.9 & 84.4 & 100 & $\begin{array}{l}\text { Middle East ( } 2 \text { I } \\
\text { and references } \\
\text { therein). }\end{array}$ & $\begin{array}{l}\text { Many countries all } \\
\text { over the globe } \\
\text { (See } 21 \text {, and } \\
\text { references } \\
\text { therein) }\end{array}$ \\
\hline $\begin{array}{l}\text { Placing object for } \\
\text { the absorbing of } \\
\text { Barakeh/divine } \\
\text { blessing }\end{array}$ & 38.2 & 37.9 & 71.1 & 57.6 & $\begin{array}{l}\text { Israel(22: Passim, } \\
\text { |76:48,5।) }\end{array}$ & \\
\hline $\begin{array}{l}\text { Personal vows/ } \\
\text { requests/petitions } \\
\text { for health/wishing } \\
\text { tree/ }\end{array}$ & 58.8 & 62.0 & 71.1 & 15.3 & $\begin{array}{l}\text { Israel (19: passim,, } \\
\text { 20, passim, } \\
21: \text { passim, 22: } \\
\text { passim, I77:I76, } \\
\text { I36:79); } \\
\text { Syria (145:296, } \\
\text { I78:I73) }\end{array}$ & $\begin{array}{l}\text { Scotland } \\
\text { (I79:499); } \\
\text { Estonia (I80:4); } \\
\text { Serbia (30:97); } \\
\text { Russia (106:322); } \\
\text { East Africa (45:4, } \\
\text { I50:263); } \\
\text { Sierra Leone } \\
\text { (I26:48); } \\
\text { Guinea - Bissau } \\
\text { (I59:389); } \\
\text { Chad (I8I:248); } \\
\text { India (I82:353, } \\
\text { I83:55-59, } \\
\text { I84:43); } \\
\text { Japan (I85:23; } \\
\text { I86:I0); } \\
\text { Australia, New } \\
\text { Zealand (I4:164) }\end{array}$ \\
\hline Weddings & 17.1 & 51.7 & 28.8 & 15.3 & Israel (20: passim) & $\begin{array}{l}\text { India }(76: 91 \\
39: 175,187: 62)\end{array}$ \\
\hline $\begin{array}{l}\text { Lighting candle/ } \\
\text { lamps }\end{array}$ & 23.5 & 24.1 & 31.1 & 65.3 & $\begin{array}{l}\text { Israel (I 36:79, } \\
\text { I } 76: 43) ; \\
\text { Lebanon }(144: 34) \text {; } \\
\text { Turkey }(88: 216 \text {, } \\
89: 80, \text { I88:4I) }\end{array}$ & $\begin{array}{l}\text { Balkan (I88:4I); } \\
\text { Russia (3I:94); } \\
\text { Uganda (I89:46I): } \\
\text { Armenia } \\
\text { (190:II:I73); } \\
\text { India (93:87) }\end{array}$ \\
\hline $\begin{array}{l}\text { Hammering of } \\
\text { nails }\end{array}$ & 8.8 & 17.2 & 8.9 & 23.0 & $\begin{array}{l}\text { Israel (:24:7-8); } \\
\text { Egypt (95:27); } \\
\text { Turkey }(89: 80) ; \\
\text { Kurdistan }(88: 216)\end{array}$ & $\begin{array}{l}\text { Europe (84: } \\
\text { passim); } \\
\text { Russia (106:320); } \\
\text { Ireland (105:195). } \\
\text { India (92:97, } \\
\text { 93:182); } \\
\text { West Himalaya } \\
\text { (94:xxi) }\end{array}$ \\
\hline $\begin{array}{l}\text { Placing stones on/ } \\
\text { under the tree } \\
\text { Leaving stones on } \\
\text { the tree or in } \\
\text { heaps/cairns }\end{array}$ & 2.9 & 10.3 & 8.9 & 26.9 & $\begin{array}{l}\text { Ancient Israel } \\
(101: 2 \mid 2) ; \\
\text { Israel (I77:76); } \\
\text { Muslim world } \\
(88: 211)\end{array}$ & $\begin{array}{l}\text { Russia (191:114); } \\
\text { India (103:19, } \\
\text { 1921:457, 458); } \\
\text { Korea (60:44); }\end{array}$ \\
\hline $\begin{array}{l}\text { Incense (as a part } \\
\text { of a personal form } \\
\text { of praying) }\end{array}$ & 5.9 & 17.2 & 24.41 & 19.2 & $\begin{array}{l}\text { Israel (193:359); } \\
\text { Syria (144:297) }\end{array}$ & $\begin{array}{l}\text { India (51:66); } \\
\text { Armenia } \\
\text { (190:11:173); }\end{array}$ \\
\hline
\end{tabular}


Table 2: Family/Personal Issues/Respect of the tree (Continued)

\begin{tabular}{|c|c|c|c|c|c|c|}
\hline $\begin{array}{l}\text { Funeral/burial } \\
\text { under the tree/at } \\
\text { the sacred grove } \\
\text { (also of leaders } \\
\text { and heroes) }\end{array}$ & 0 & 24.1 & 20.0 & $\begin{array}{l}\text { 23.0 Existing } \\
\text { tombs/cemet eries }\end{array}$ & $\begin{array}{l}\text { Ancient Israelites, } \\
\text { (Genesis 35:8); } \\
\text { Israel (I37:37, } \\
\text { 136:74). }\end{array}$ & $\begin{array}{l}\text { Mongolia } \\
\text { (I29:280); } \\
\text { Zimbabwe } \\
\text { (194:200, } \\
\text { 195:164); } \\
\text { Kenya (196:6); } \\
\text { Ghana (197:34, } \\
\text { 198:225); } \\
\text { Mozambique(I22: } \\
\text { 229); } \\
\text { Tanzania (199:59); } \\
\text { Okinawa (161:48); }\end{array}$ \\
\hline $\begin{array}{l}\text { Tree Embracing/ } \\
\text { touching/kissing }\end{array}$ & 55.9 & 6.9 & 4.4 & 7.7 & & $\begin{array}{l}\text { Ancient Rome } \\
\text { (200, XVI: 242); }\end{array}$ \\
\hline $\begin{array}{l}\text { Leaving objects/ } \\
\text { food under tree as } \\
\text { charity }\end{array}$ & 26.4 & 20.6 & I 5.5 & 30.7 & & \\
\hline $\begin{array}{l}\text { Praying while } \\
\text { passing near the } \\
\text { tree }\end{array}$ & 0 & 6.9 & 7.7 & 0 & & \\
\hline $\begin{array}{l}\text { Cleaning around } \\
\text { the tree }\end{array}$ & 5.9 & 10.3 & 2.2 & 23.0 & & \\
\hline
\end{tabular}

\section{Wedding preparations under sacred trees}

In some villages there are sacred trees which are called "Sajarat el Orsan (the groom's tree, 8) or "Sagarat el Arus (The bride's tree, 7). These names reflect the old custom of performing weddings under these trees. Just before the ceremony at the groom's house he was brought to the sacred trees for final preparations (Zaffa). Mats were spread under the tree and food and sweets were offered to the guests. A group of males surrounded the groom and washed him, he was then dressed in beautiful clothes and his friends used to encourage him while the women gathered nearby singing special songs. Sometimes horse races were held on the same occasion. Later the groom was brought in a special ceremonial parade to his home in which the official meal was held. (This ceremony or parts thereof were common in many villages, 12, all of which are Muslim). Weddings under sacred trees are known also among the Druze; here it is more of a kind of feast or celebration - but without special attention being paid to the groom, 10). When people were asked why the ceremony was held under the tree some ( 7 , Arabs) they said that it was to get a blessing, while others (5, Bedouins) mentioned that the large solitary tree was a good place for gathering under as it offers much shade in the summer and is a good place for horse racing. The Druze (5) mentioned the pleasant and spacious area around the tree as the reason for choosing it as the place for the celebration, while others (4) indicate that it was done "for a blessing".

\section{Rainmaking rituals}

The rainmaking ceremony at the village of Kaukab Abu el Heija, in the Western Galilee, was so famous that people from other villages in the region used to take part and each delegation brought its special flags which were assigned for this specific purpose. When there was a rain arrest, the rainmaking parade was leaving the village from the sacred saint's shrine of Sheikh Sa'eed (in which the flags and the musical instruments are deposited even today) to the close mountain (Mt. Atzmon). The participants were equipped with their flags and special musical instruments. On the way they stopped at a sacred tree (Christ Thorn Jujube, Ziziphus spina christi, the tree had already disappeared) and they put the "rainmaking flags" near this tree. Here they read the opening chapter of the Quran (Surrat el Fatikha) while asking another saint (Abu El Heija, the local saint, buried on an adjacent hill) for a permission to continue the ceremony. Then they approached his grave and circumambulated it seven times while praying.

The parade continued to another sacred tree; underneath it was the grave of Sheikh Ottoman (the tree of Pitacia lentiscus and the grave has already gone) and circumambulated it seven times with the flags. Then they climbed the mountain which is close and prayed near an impressive tree, an evergreen oak (Quercus calliprinos), circumambulated the mountain peak and prayed for rain. They then returned to the village in a special track (along a special path) which is called "the way of the musical instruments 
and the flags" and the rain begun soon. The last ceremony was held around 1953 (8).

In other villages we heard that rainmaking ceremonies and praying were carried out near sacred trees, they included special songs and prayers (which may have varied from village to village) and sometimes included the sprinkling of water. (10, from six different villages, all of which are Muslim), these ceremonies came to an end over the last three to five decades.

Rain making ceremonies at the Druze sector are quite rare and performed (mainly as water pouring and special songs, 8) by woman and children in the streets and are never related to sacred trees. The religious leader considering rainmaking ceremonies as a kind of an intervention in God's action. A popular saying, reflecting this view, says "My son doesn't look at the cloud, God's mercy is closer" (Salekh Khatib, 22.4.07. Pers. comm.,)

\section{Discussion}

\section{The tree as a social centre}

In many cases it is easy to attribute meetings under the tree not to its sancticity but simply because many of them are very large and give a lot of shade (5). As a rule, in Israel, there are no official religious meetings under a tree and it is not a centre of communal worship as in many polytheistic religions.

\section{Judging under the tree}

Judging under trees is known from Biblical times (Judges 3:5). Hamilton [[27]:59] reports that, even today, no Hindu or Buddhist shrine is completed without a sacred tree planted nearby. These large trees (pipal and banyan) have become natural assembly points for village meetings, community events, and the dispensing of justice. In central Europe, the most venerable oak in many towns and villages became a site of justice where the magistrate sat when he passed judgment [[14]:145-146], and those trees were preserved as "justice trees" [[27]: 61-62].

\section{Sacrifices under the tree}

Sacrifices have been carried out since time immemorial in almost in every known culture, to propitiate gods and spirits, to restore the divine connection and to wipe out the offence, [[28]: passim], according to this author [[28]: VII] "...The world was once seen to be alive with gods and spirits needing nurture and propitiation. If offered the right sacrifices, they would dispense aid and grant special favours". Because sacred trees/groves were regarded as the abode of spirits/gods/supernatural beings (see review in[15]) it is not surprising that sacrifices were offered under these trees and groves in various religious ceremonies [[12]:1926:passim; Sudan, [29]: 458,461; Slavs in Europe, [30] :97; Russia, [31]: 66,113; Nigeria, [32]:
42,46; Ghana, [33]:599,603; Tanzania, [34]:16; Senegal, [35]:420; Senegal, [36]:5] and even human sacrifice in the past (Nigeria, [37]:74; India, [38]: passim; [39]:29,245,484;565,568; [40]:344; Thailand, [41]:107; Indonesia,

[[42]:165].

In the world of Islam "the great majority of sacrifices are made in payment of vows furnished to some saint. As soon as the animal is killed, it ceased to belong to the one who offered it and becomes the property of the Weli (the local saint)" [[43]:172]. The common tradition is to share the meat with other people including needy ones [Palestine, [19]:165; [20]: passim, Morocco, [44]:457]. Such a sacrifice is made at saints' graves and shrines [[19]:154174; [20]: passim; Morocco, [44]:457] as well as under sacred trees (Table 2). At present, a goat or sheep maybe is dedicated to the saint as a part of the fulfillment of a vow and as a form of thanks for the granting of a personal request [[19]:158, the animal is slaughtered at the saint's shrine [19]:160; [20]: passim]. near the sacred tree and the meat is given to the needy and/or used by the family (48). This kind of sacrifice is also known from: Nigeria [[37]:52; East Africa, [45]:4; Morocco, [44]:457 and Palestine [19]:158]. This custom has nothing to do with a sacrifice to any supernatural being that is related to the sacred tree or the grove in which sacrifices are part of the official religion (see above).

\section{Sulkha}

Sulkhas being conciliations between families, especially when serious quarrels or murder were involved. In the village of Arab a' Shibli (in the foothills of Mt Tabor) there is a special tree (Quercus ithabusresis) named Al Mizar (= the visits) under which the local judges used to sit regularly until around 1950 (17 informants from this village). Near this village there was another oak tree (named "Sajarat el Bahta") near which Sulkhas were carried out (6). The act of a "Sulkha" under the tree seemed to prevail, in the past, more in Bedouin than in Arab villages and was not found by us among the Druze.

So far this custom (performed under a sacred tree) was found by us only among the Bedouin. Sulkha procedures are very common among the Arabs and are held generally at the leader's (Sheikh's) house. It seems that among the Bedouin it is carried out under the tree especially because it is a well-shaded place; not one of our informants has pointed out a special connection between the sacred tree and the saint that is related to it.

\section{Rain making ceremonies}

Rainmaking ceremonies are known worldwide in many diverse communities [[12]: passim]. A rainmaking ceremony may contain one or more of the following elements: water pouring, imitation of rainfall and thunder 
prayers, use of musical instruments/special songs, sacrifices and the use of special objects for these ceremonies. The ceremony is carried out by special members of the community; it is a secret ceremony, which takes place in special places frequently sacred ones, there is the performing of a special procession, as well as special costumes. These elements or parts thereof were reported from many countries [Palestine, [19]: 219-234; Zimbabwe, [46]:356; Kenya, [47]:139-140; [45]:4; Uganda, [48]:62,71,72; Central Africa, [49]:53-55; Sudan, [50]:54; India, [51]:67; [34]:330-332; [52]:476-477; Papua, [53]:390; Tunisia, [54]:passim; India, [55]:143-174; Japan, [56]:1-30; Ghana, [33]: passim; Chad, [57]:230]

One may suggest several reasons why rainmaking ceremonies are performed near/under sacred trees/groves/forests and/or large trees:

1. The tree/grove is associated with the rain/thunder god. According to Ruppert [[55]:143] "the sources of rain were conceived in various ways, most commonly as one form or another of deity, especially associated with the heavens or with creation in general". The tree is the abode of the sky/cloud/rain/thunder divinity who is "in charge" of rain [Ancient Greece, [58]:8.38.4; Pagan Europe, [59]: passim; [60]:31, 34-36; Uganda, [48]:59, Papua, [53]:388; Sudan, [50]:53; Central Africa, [49]:53-55; India, [51]:67; Zimbabwe, [46]:358,361]. Thus, it is not surprising that rainmaking ceremonies were carried out under the sacred trees (Table 1) as they are considered to be the abode of the supernatural beings which bring the rain.

2. Gerden \& Mtallo [[34]:45] explain the connection between sacred trees and rain making ceremonies "The trees... are important for the formation of clouds that move up to the peak of the mountain... According to local belief, when clouds ascend it is a sign that rains will start. If the trees are cut, no clouds would come up to the mountain top and there would be no rains"

3. The tree is the abode of the supernatural beings that protect the village and take care of its prosperity. Chidahakwa [[61]:6; Zimbabwe] stated:" Some sacred trees are places were rain ceremonies are conducted and are regarded as the protectors of the village and the seat of the ancestors" [also in Chad [57]; 235].

While considering the possible connection between sacred trees and the rainmaking ceremonies in Israel, one should bear in mind that these ceremonies were common, in the past, in almost in every village, regardless of any trees [[19]:219-233]. In general, throughout the Moslem world, rainmaking ceremonies are performed at saint's shrines [[18]: II: 256]. Because sacred trees are regarded as the abode of the saint's soul [[19]: 151; [15]; passim], rainmaking ceremonies could be regarded as another aspect of using the sacred tree as a channel to the merciful god asking for his favour as it is done in many other cases of trouble [[19]:151 [21,15,22]; passim].

Palmgrave [[62]: I: 11-12] described a rainmaking ceremony in Arabia around an Acacia tree which also includes prayers and dances and mentioned that it was a pre-Muslim relic. Thus it is another manifestation in which tree worship of old local deities were replaced, in the Muslim world by a veneration of the saint. [[16]:316; [19]:151; [15,21]: passim]. According to Westermarck [[17]:122] Muslim Saints "may influence the power to produce rain as one of the gifts most frequently ascribed to them" [see also [19]:271 who mentioned that saints may prevent rain]. Canaan [[19]:219-230] mentioned that requests for rain are made frequently at saint's shrines, some of whom are known to be more efficacious than others in giving blessings and their shrines are preferred for rain processions [[19]: 227]. This also explains why these ceremonies were confined to Muslims: the Druze do not consider sacred trees as an abode of any soul [22]. Sacred trees are not mentioned in relation to requests for rain in the entire chapter that is devoted to rain procession in Canaan [[19]: 219-234].

Rainmaking ceremonies near sacred trees are the only situation that the present author is aware of, in which a request using sacred trees for asking of a favour is for the whole community and not only for the welfare/health/ benefit of the individual person and/or his family. Public petitions for the whole community (which are not related specifically to rain-making) are held in many polytheistic religions under sacred trees or groves which are the abode of the protecting god of the village [[63]:113; Kenya, [64]:89; Mozambique, [65]:14; Laos, [66]:324; China, [67]:352; [68]:6; [69]:131-132; India, [70]:8; [71];345; [72]:66-68; [73]:2001; [74]:151:315-319, [75]:384, [76]:96; East Africa, [77]:414,432; Ivory Coast, [78]:370; Nigeria, [79]:290,292,293; Ghana, [80]:366; [81]:159; Timor, [82]:90-99; Vietnam, [83]:113; India, [72]:67 and Chad [57]:230] one of the possible punishments for the violation of such trees is rain stopping.

\section{Rag tying}

It seems that the custom of tying rags onto sacred trees exists in almost every known human culture, going beyond the borders of religion, geography and time [[84]:passim; [85]; I: 111; [12]:7-96, see [21] for a review]. Rag tying is largely distributed in the Moslem world [[16]:316]. Rix [[86]:32] noted that clothes that are left on sacred trees are not just gifts in the ordinary sense; rather, they are channels connecting the worshipper with the object or person worshipped. In the Moslem world, rags, used clothes, yarn and threads are tied, in the shrines 
or tombs of holy figures (Wellis) and on objects around them such as sacred trees, the wire netting which covers the windows of saints' tombs, fences, [[86]:180].

Curtiss [[43]:92; [18]: 562; [19]:103] in order to get the saint's divine blessing ("Barakeh"). Rix [86]:32] mentioned, "Holiness is, indeed, to the Palestine peasant a sort of liquid which may be absorbed by physical contact. The man who hangs a rag upon a tree will take from it and wear about his person another rag which has become soaked with the virtue of the place by hanging there..."

Dafni [21] found seventeen reasons for tying rags on sacred trees worldwide, twelve of which were recorded in Israel: Five reasons (the breaking of an existing oath, to mark a blessed tree, to mark the road to a blessed tree, to ask for permission to pick fruit and to leave rags for needy people) which are endemic to the Druze. Two reasons (to pacify the tree's spirit and a charm for new clothes) were previously reported from Israel but were not confirmed. Three other reasons (transference of one's illness to the tree, using a rag as a visiting card and to pacify the tree's spirits) are also known beyond the Middle East. Other reasons (such as ensuring good crops, offerings to the tree's deities/spirits, pacifying the ancestor's spirits, commemorating a death, pacifying a tree's spirit while picking fruit) were never reported from the Middle East and are connected with polytheistic religions.

\section{Hammering nails into sacred trees}

Hammering nails as well as hanging clothes are "tying" rituals, whereby the person seeks healing or a solution to problems by transferring his or her illness or problems to the tree, or to whatever object the clothes are hung on or nails hammered into. Such "tying" is one of the best known and commonest beliefs practised throughout the world among Christians, as well as among Muslims and their predecessors in the Middle East [[88]:213; [89]:262; [21]]. Hartland [[84]:459-460] has already identified the common background of hanging rags and putting nails on sacred trees as "generally the attainment of some wish, or granting of some prayer, as for the husband, or for recovery from sickness".

In several countries nails are hammered to a sacred tree to transfer the pain or illness into the tree [England and Germany [90]:493; Kurdistan, [88]:216; Europe, [84]:58; and Turkey [89]: 176,262; [91]:128].

In India the emetic nut tree (Strychnos nuxvomica) is considered the prison of all demons. Occasionally such trees can be seen with trunks full of nails as a precaution against demons. If a demon or bad spirit dares to attack a human, the exorcist forces it back into the tree with a nail. With each nail driven in the demon declares that it will not attack again. Nailing the demon into the tree trunk is the best way to give it a life sentence [[92]:97; [93]:183]. Sacred trees in the West Himalayan region are the object of a similar custom: travelers hammer nails into the trunk when passing by as a protective step against diseases, death, and any damage to their sheep, cattle, or crops. The explanation for this act, according to traditional belief, is that it dispels evil powers [[94]: xxi].

In Egypt, nails driven into tree trunks signify the prayers of the believers. People come to sheikhs' trees to be cured of headaches or other ailments. In asking the sheikh for help, they hammer nails into the trunk and wind some of their hair around the nails [[95]:56]. A ceremony of this kind was recorded at sacred graves in Turkey [[89]:80]. Some are of the opinion that this was a gypsy tradition introduced from India [[96]:147]. Our informants (8) mentioned that nail hammering is done against the evil eye as "A nail in the eye of Satan" (4).

A square in central Vienna is named Stock am Eisen, which means literally "iron on the stick". A glass case stands on one of the corners of the square containing a replica of a piece of wood into which some nails have been driven. A known tradition from the $16^{\text {th }}$ century relates that any apprentice who completed his duties in the town would hammer a nail into a tree that grew in the square for good luck [[97]:21; [98]:99].

Some authors mentioned that nail hammering is done just to fix clothes/rags [Europe, [84]:453,454; Scotland; [99]:75; Yemen, [87]:213-214] or money to the tree [[98]: 75].

\section{Leaving stones on/under the tree}

Stones are put in certain places when people died as a token of honour to the deceased [Ireland, [100]:43; Morocco, [18]: II: 549; [101]:212, Israel (Bedouins: Negev) [102]:76], this custom is very common today in Europe as well as Israel (personal observation].

In the Muslim world it is common to put a stone on or under sacred tree "when a woman yearns for a child, when a peasant longs for rain, or when he yearns for the restoration to health or his horse or camel" [[88]:211]. According to Westermarck [[18]:1: 75-76] cairns are placed under sacred trees for curing just as they put rags or threads. Canaan [[19]: 75] mentioned that stones are placed in heaps at saints' shrines to show piety and as a visiting card. In India believers put stones under a sacred tree as part of a worship of a local deity that dwells in the tree [[103]:19] and in Korea as an offering [[60]:44]. Not one of our informants was able to explain why stones are left on or near sacred trees although stones on sacred trees are quite common (Table 2). 


\section{Leaving money on/under the tree}

In Israel, people used to leave money under the tree as well as in saints' graves ( 5 informants, Leaving money in graves is a very common custom in the Muslim world [[18]: II: 502; [104]:159] as charity for the needy (6). Money is left on trees when a wish is made as an offering to the supernatural being to ensure the fulfillment of the personal request and for wishes and good luck [Scotland, [98]:75,76; Ireland, [105]:195; Europe in general [84]:passim; [106]:322].

\section{Weddings}

People used to arrange weddings under the sacred tree to receive blessings from the saint to whom the tree is dedicated (24) and, also, just because it was almost the only large available tree that gave considerable shade $(5$, all of which are Bedouin who stressed that the tree was a meeting point because of this very reason). In some villages there are special sacred which were used for the pre-wedding ceremonies. Weddings under a sacred tree can still be seen in the village of M'ghar (Lower Galilee) under the huge Ziziphus spina christi of Sheikh Rabis. This custom was more common among the Bedouin in rural areas but quite rare among the Druze whose religious leaders are strictly against this custom (4).

\section{Taking vows}

Vows are taken under a sacred tree just as they are in saints' shrines [[19]:132-133]. This is frequently manifested by tying rags in the shrines or on sacred trees [see [21] and references therein]. The religious belief is that these places are regarded as channels between God and his believers through the saint's mediation in his place [shrine or a tree, see [22], passim; [15]: passim; [19]:3538; [16]: 21].

\section{Incense}

According to Groom [[107]:1] "Incense has had a continuous religious significance throughout the entire expanse of history from the first civilization to the present day...It was used ...to purify and to please gods and as an offering to the gods". The use of incense was very important in Jewish traditions in Biblical times [Bible citations; [108]: passim; [109]:71]. Burning incense under a sacred tree is already mentioned by the prophet Hosea [[4]; 13] when he complained of the practising of tree worship in Israel.

Groom [[107]:2] explains the use of incense "The spreading of the smoke and fragrance of incense and the visible movement of the smoke upwards towards the heaven has given it a symbolic relationship to prayer, making the offering synonymous with worship". When our informants were asked why they used incense (under the sacred tree) the answers were: for barakeh (16), to honour the saint (9), against the evil eye (4, as it is known in Jewish communities [[108]:13] as well as in the Arab traditions [[19]:148] and for a good odour (5). The common incense stuff is dried leaves of Salvia fruticosa which is frequently used locally also in rites of passage [[110]: passim]. The burning of incense is very common at saints' shrines [[107]:2-3; Palestine [19]:148,249; Morocco, [18]: I: 123].

\section{Candles/oil lamps lighting}

Candles, as well as other kind of light sources, are used all over the world in religious ceremonies as explained by Weightham [[111]:59]. "The presence of light as the manifestation of the holy spans multiple religions. Light, through its presence or absence, sets apart the sacred from the profane"

Candles and oil lamps are lit on the graves of righteous people and saints by Jews as well as Muslims in Palestine [(Moshe Yerushalmy 1769 in [112]:431; [113]:38] as well as in Morocco [[44]:459]. Candles and oil lamps are also lit at saints' shrines [[19]:96]. Candles are lit in general while making a vow [[19]:132; 23]. personal praying (18) or as a regular commitment (generally on certain days of the week, especially Thursday night) to the saint as a result of a vow (7)

Westermarck [[18]: I: 302] explained the use of candles" The Jinun (devils) are fond of darkness and terrified by light. The burning of candles is therefore a means of keeping them away". Our informants explain candle lighting as for Barakeh (7) and as thanks (6) to the tree/saint as it is also done in a saint's shrine [Canaan, 1927-8:19:132].

\section{Use of sacred parts of trees}

In the Middle East, parts of the trees may be taken as talismans/charms/amulets/medicine because the tree had the divine blessing of the saint " ("Barakeh") to whom the tree is dedicated [[19]: passim; [20]: passim; see [22] and references therein]. The influence is based on magic contact; this has also been noted in Europe [[114]:18]. moreover, religious objects made from the wood of the sacred tree are known in other parts of the world, especially in India [[115]:44].

Sacred trees are believed to have magical curative powers in pagan Europe [[116]:276-277; [117]:42-45; [118]: I: 169-193]. In Israel, even species of some plants or parts of it that are not known as having medicinal properties, such as the leaves of a sacred oak (Quercus calliprinos), are regarded as omnipotent forms of medication when administrated externally as a poultice (6) or as a decoction (8). Leaves of a "secular" oak are not used for healing. Clearly, the leaves acquire the healing powers only when granted by saints; just as actual medicinal plants gathered in the vicinity of the sacred tree are more potent than their 
conspecifics (5). Most of the uses of sacred trees for divine blessings or cures or as talismans (Table 2) are based on a magical contact.

In our survey it was found (Table 2) that individual people may use parts, especially the leaves of the tree only as carriers of the saint's divine blessing (Barakeh). Sacred trees are never used as a part of an official religious ceremony.

The use of parts of sacred trees (especially specific species) is very common in India, especially when the specific trees are sacred to a certain deity [115]: passim; [11]: passim; [93]: passim] as part of the fulfilling of daily rituals (especially leaves and flowers), also in Nigeria [[119]:125,129].

\section{Charity}

Visitors to sanctuaries, in Palestine, used to leave objects in honour of the saint as votive objects, as part of a fulfillment of a vow or for use by later visitors; these included candles, oil for lamps [19]:144-146, also personal observations], incense [19]:148] and matches [19]145]. It is unique to the Druze believers to leave used clothes at sacred trees as a charitable gift for use by other people [21].

\section{Decorating the tree}

The Druze sometimes put pictures of their religious leaders on sacred trees (Table 2) as they used to do in their house of prayer (Hilwe) and other sacred places (personal observation.). When they declared a "new" tree as sacred on Mount Carmel [see [15]] they decorated it with such kinds of pictures. The reason given was "hanging pictures brings blessings" (4). So far this custom has been found only in the Druze sector.

In addition to the great fear of punishment due to harming or making sacrilegious utterances about the trees [see [22]], there are many gestures which show the deep respect for the trees; these are performed while approaching or visiting the tree such as a ban on defecating or urinating near the tree (3), swearing (3), cleaning around the tree (Table 2); a need for personal purifying (e.g. washing before visiting the tree as is done before a visit of the mosque) (5); the saying of a special chapter from the Quran (18); and it is forbidder to leave ant dirt under the tree (5).

\section{Kissing and embracing of the tree}

This custom seems to be almost exclusive to the Druze. They (13) explain that kissing the "blessed tree" [see [15]] is to receive a blessing as the kissing is done in a sacred grave 6). The same is regarded for putting the palm of one's hand on the tree (5). In India, people embrace a sacred tree in order "to get their desires fulfilled" [[103]:23].

\section{Sacred trees, saint's graves}

In the discussion about the reason/s for the sanctification of trees [[15] passim; [18]: passim]. it is agreed that there is a similarity between sacred trees and graves of Muslim saints (Wellis). The spirit of the Welli dwells in his grave or his shrine or in a tree which is dedicated to him. It is not surprising to see the close similarity between the ceremonies and rituals that are performed in a saint's shrine/ grave and at a sacred tree.

Many of the rituals and ceremonies that are held at the sacred tree first take place at the saint's shrine or his grave. Analysis of the places where ceremonies and rituals are performed [[20]: passim; [19]: passim] shows that the sacred tree is only regarded as such as a kind of a "default"; there is also a kind of hierarchy among the saints: some of them are regarded as more powerful in their supposed powers. For example Canaan [[19]:133] has already mentioned "Vows are not only made to sanctuaries where a maqam (saint's shrine) and a tomb are found, but every other shrine.......Naturally what is vowed to these shrines stones, trees, caves, springs, etc. - is as a rule much inferior to what is offered to the anbiya (= prophets). Offerings to supposedly holy stones, trees, waters, etc., are another connecting link with primitive religions". When it possible sanctuaries and saint's shrines are preferred to trees [[19]:passim; [19]: passim]. Thus it is not surprising that sacred trees replaced graves and shrines in their absence or when they were more available at a local level.

\section{Monotheistic vs. polytheistic sacred trees}

In many polytheistic communities there is a close relationship between sacred trees/groves and burial places which show the close links between ancestor's souls and tree worship [Taiwan, [120]:5,III,I; China, [121]:133; Mozambique, [122]:131; Ghana, [123]:41; [80]:366; Madagascar, [124]:19-20; Zimbabwe, [61]: 6]; Sierra Leone, [[125]:47]; Rhodesia, [126];102; Kenya, [127]:1350; French Guinea, [128]:14; Inner Mongolia, [129]:277,280; India, [130]:242; [131]:332; Laos, [132]:4; Indonesia, [[133];310,318; Papua, [134]:72]; Australia, [[135]:163].

Although there is a connection, in monotheistic religions, between sacred trees and burial sites it is not related, nowadays, to any form of ancestor worship. In Israel, sacred trees are frequently located in cemeteries, sometimes heroes or important people are buried under the sacred tree as a token of special homage [[136]:74; [137]: passim]. This custom is not related to ancestor worship (see references above) and sacred groves as the community 
burial places [see references above and in [15] and references therein] are unknown.

Dafni [22] has already noticed that in the Middle East, as well as in Europe, tree worship today is practised by individuals making personal petitions. Tree worship is, by no means, a part of the official monotheistic governing religion. In Israel there are no performances of regular religious ceremonies, as they may be held in a maqam (a saint's shrine) [[19]:98] or of, course, in a mosque that is performed at a sacred tree. Nevertheless, in many polytheistic religions, tree worship is a part of the official worship and is performed at a community-based level [see discussion and references in [22]].

\section{The uniqueness of some Druze customs}

Some customs such as rainmaking ceremonies, burials, pronouncing judgment, conducting a Sulkha, and leaving water under the sacred tree are absent in the Druze sector.

As far as the author is aware, rain-making ceremonies are almost unknown in this sector in relation to sacred trees, although they were previously common in the villages (6).

The Druze believe in the transmigration of souls: a person's body is a kind of clothing for the soul and, with death, the soul passes to the body of a newborn child [[26]:60]. The Druze never consider sacred trees as an abode for the souls of righteous figures and certainly do not relate trees to graves [see [22]]: for further discussion. However, some Druze ascribe supernatural powers to sacred trees [22]. Their fear and admiration of such trees are of the same magnitude as in the Muslim sectors [(Tables 1 and 2, and [22]]. While the Muslims credit the miraculous powers (e.g., the trees' immunity to fire) to the souls of Wellis or of God, the Druze ascribe these powers to their prophets or religious leaders themselves [22].

\section{Conclusion}

When comparing the customs and ceremonies which are held, in many cultures, in sacred places and religious shrines as well as under sacred trees and groves one may come to several conclusions:

- 1. Sacred trees are just another kind of sacred place with all their metaphysical as well as physical manifestations. In our region, sacred tress are frequently related (by Muslims) to the shrines of saints

- 2. There is not even one ceremony or custom that is peculiar only to a sacred tree and is not performed in relation to other sacred places (such as a saint's grave or mosque).
- 3. Few customs (e.g. the settling of quarrels = Sulkha), leaving objects to absorb the divine blessing and leaving objects for charity) seems to be characteristic of the Middle East

- 4. Sacred trees were never recorded in modern times, in our region, as centres for official religious ceremonies including sacrifices, or places for the performing of rites of passage.

- 5. There are some variations among the different ethnic groups: The kissing and worship of trees is more common among the Druze while burial under the tree, leaving water and rain-making ceremonies under the tree was not recorded in this group. Passing judgment under the tree is more typical of Bedouin communities in which the sacred trees were commonly used as public social centres.

Most of the customs/manners related to sacred trees and groves are ubiquitous and can be found throughout human history. Some of these, such as family gatherings, conducting a Sulkha, the leaving of food, the leaving of objects to absorb divine blessings and leaving objects for charity) seem to be characteristics of this region, while the performing of official religious ceremonies under the sacred trees was never recorded in present-day Israel and is typical of the old Semitic religions [[43]: passim]. Today, these ceremonies exist mainly in polytheistic religions.

\section{References}

I. Turner HW: From Temple to the Meeting House: The Phenomenology and Theology of Places of Worship. The Hague: Mouton; 1979.

2. Eliade M: The Sacred and the Profane. (Transl. Trask WR :). San Diego, New York and London: Hartcourt; 1957.

3. Durkheim E: The Elementary Forms of Religious Life (Transl. K.E. Fields). New York. Free Press; 200I.

4. Eliade M: Patterns of Comparative Religion. New York: Sheed \& Ward; 1958.

5. Davidson LK, Dunn-Wood M: Pilgrimage in the Middle Ages - A Research Guide. New York and London: Garland Publishing; 1993.

6. Hubert J: Sacred beliefs and belief of sacredness. In Sacred Sites, Sacred Places Edited by: Carmichael DL, Hubert J, Reeves B, Schanche A. London and New York: Routledge; 1998:9-19.

7. Carmichael DL, Hubert J, Reeves B, Schanche A: Sacred Sites, Sacred Places London \& New York: Routledge; 1994.

8. Caillois R: Man and the Sacred (Transl. M. Barash) Westport, Connecticut: Greenwood Press; 1980.

9. Cummins G, Whiteduck K: Towards a model for the identification and recognition of sacred sites. In Sacred Lands Edited by: Oakes J, Riewe R, Kinew K, Maloney E. Albereta: Aboriginal World Views, Claims and Conflicts Canadian Circumpolar Institute, University of Alberta Occasional Publication. No.8. 1998H; 1998:3-I4.

10. Sinha BC: Tree Worship in Ancient India. London and The Hague: East-West Publications; 1979.

II. Gupta SS: Sacred Trees across Cultures and Nations. Calcutta: Indian Publications, Folklore Series 27; 1980.

12. Frazer JG: The Worship of Nature. London: Macmillan; 1926.

13. Philpot JH: The Sacred Tree or the Tree in Religion and Myth London: MacMillan \& Co; 1897.

14. Altman N: Sacred Trees San Francisco: Sierra Club Books; 2000.

15. Dafni A: On the typology and the worship status of sacred trees with a special reference to the Middle East. J Ethnobiol Ethnomedicine 2006, 2:26-4I. 
16. Goldziher I: Muslim Studies Edited by: Stern SM. London: George Allen and Unwin Ltd; I97I.

17. Westermarck E: Pagan Survivals in Mohammedan Civilisation Amsterdam: Philo; 1933.

18. Westermarck E: Ritual and Belief in Morocco. New York: University Books; 1968. (First published in 1926)

19. Canaan T: Mohammedan Saints and Sanctuaries in Palestine. Jerusalem: Ariel (Originally published 1927-1928, rep n.d.).

20. Arraf S: The Status of the Prophets and Saints in the Holy Land Tarshikha: Ikhan Mahul; 1993. (In Arabic)

21. Dafni A: Why are rags tied to the sacred trees of the Holy Land? Econ Bot 2002, 56:3।5-327.

22. Dafni $A$ : The supernatural characters and powers of sacred trees in the Holy Land. J Ethnobiol Ethnomedicine 2007, 3:10.

23. Frese PR, Gray SJM: Trees. In The Encyclopaedia of Religion Volume 15. Edited by: Eliade M. New York: Macmillan Library Reference USA, Simon and Schuster and Macmillan; 1995:26-33.

24. Dafni A, Levy S, Lev A: The ethnobotany of Christ's Thorn Jujube (Ziziphus spina christi) in Israel. J Ethnobio Ethnomedicine 2005, I:I2.

25. Medzini A: Expansion of Bedouin settlement in Galilee resulting from spontaneous occupation and planned government policy. In Monogeography No. I Haifa: Department of Geography; University of Haifa; 1984.

26. Dana N: The Druze in the Middle East - their Faith, Leadership, Identity and Status. Brighton and Portland: Sussex Academic Press; 2003.

27. Hamilton LS: Forest tree conservation through metaphysical constraints. The George Wright Forum 2002, 19:57-78.

28. Lewis BR: Ritual Sacrifice: An Illustrated History. Phoenix Mill, Thrupp, U.K: Sutton; 200I.

29. Seligman CG, Seligman BZ: The Bari. J Roy Anthropol Soc Gr Brit Ire 1928, 8:409-479.

30. Kemp P: The Healing Ritual Studies in the Technique and Tradition of Southern Slavs. London: Faber \& Faber \& School of Slavonic and East European Studies, University of London; 1935.

31. Abercromby J: The beliefs and religious ceremonies of the Mordvins. Folk-Lore J I889, 7:65-135.

32. Greenberg JH: The Influence of Islam on a Sudanense Religion New York: J.J. Augustin; 1946

33. Fortes M: Ritual festivals and social cohesion in the hinterland of the gold coast. Amer Anthropol, New Series 1936, 38:590-604.

34. Gardén CA, Mtallo S: Traditional forest reserves in Babati district, Tanzania - a study in human ecology Uppsala: Swedish University of Agricultural Sciences, International Rural Development; Working Paper No. 128; 1990.

35. Searing JF: "No king, no lords, no slaves": ethnicity and religion among the Sereer-Safèn of western Bawol, I700-19|4. J Afri Hist 2002, 43:407-429.

36. Fayet MJC: Customs of the modern Oulof (Circle of the Boreal). Publications de Comitē d'tudes Historiques et ScientifiquesDe L'Afrique Occidentale Française. Serie A, no 8. Paris; 1939.

37. Basden GT: Niger Ibos: a description of the primitive life, customs and animistic beliefs etc., of the Ibo people of Nigeria London: Cass; 1966.

38. Bhagwat $D$ : Tribal gods and festives in central India. Asian Folk Stud 1968, 27:27-106.

39. Archer WG: Tribal Law and Justice a Report on the Santal New Delhi: Concept Publishing House; 1984.

40. Roy SC: Magic and witchcraft of the Chota-Nagpur plateaux - astudy in the philosophy of primitive life. J Roy Anthropol Ins Gr Brit Ire 1914, 14:324-350.

41. Hares M: Community forestry and environmental literacy in northern Thailand: towards collaborative natural resource management and conservation. Dissertation, Faculty of Agriculture and Forestry, University of Helsinki; 2006.

42. Appell GN: The Rungus Dusun. In Essays on Borneo Societies Edited by: King VT. Oxford: Oxford University Press; 1978: 143-171.

43. Curtiss SI: Primitive Semitic Religion to-Day London: Hodder and Stoughton; 1902

44. Marcus AM: "The saint has been stolen": sanctity and social change in the tribe of eastern Morocco. Amer Ethnol 1985, 1 2:455-467.

45. Beech MWH: The sacred fig-tree of the A-Kikuyu of East Africa. Man 1913, 13:4-6.

46. Mandondo A: Trees and spaces as emotion and norm laden components of local ecosystems in Nyamaropa communal land, Nyanga district, Zimbabwe. Agri Hum Val 1977, 14:353-372.

47. Beresford-Stooke G: An Akamba ceremony used in times of drought. Man 1928, 28:139-140.

48. Driberg JH: Rain-makingamong the Lagno. J Roy Anthropol Soc Gr Brit Ire 1919, 49:52-73.

49. Hobley CW: Further researches into Kikuyu and Kamba religions beliefs and customs. J Roy Anthropol Soc Gr Brit Ire 1922, 4I:406-457.

50. Evans-Pritchard EE: A note on the rain makers among the Moro. Man 1938, 38:53-56

51. Gupta SS, (Editor): Tree Symbols and Worship in India - a New Survey of a Pattern of Folk Religion Calcutta: Indian Publications; 1965.

52. Sanders T: Rain go bad, woman gone mad: rethinking gender rituals of rebellion and patriarchy. I Roy Anthropol 2000, 6:469-486.

53. Williams FE: Rain-making on the river Moreland. J Roy Anthropol Inst Gr Brit Ire 1929, 59:379-397.

54. Abu Zahra N: The rain rituals as rites of spiritual passage. Int If Middle East Stud 1998, 20:507-529.

55. Ruppert BO: Buddhist rainmaking in Early Japan: the dragon king and the ritual careers of esoteric monks. Hist Relig 2002, 42: $143-174$.

56. Landau PS: When rain falls: rainmaking and community in a Tswana village, c. 1870 to recent times. Inlt J African Hist Stu 1993, 26: I-30.

57. Haruna A: Rituals and ceremonies accompanying rain making among the Guruntum and Bubbure people. In L'homme et l'eau dans le bassin du lac Tchad Edited by: Jungraithmayr H, Barreteau D, Seibert U. Francfort: Paris Ostrom (Colloques et Séminaires), Séminaire du Réseau Méga-Tchad:227-239. 13-14.5.1993

58. Pausanias: Description of Greece Volume 5. Edited by: Jones WHS, Ormerod HA. Harvard: Loeb Classical Library, Harvard University Press; 1918.

59. Cook AB: Zeus and the Oak. Class Rev 1904, 18:75-89.

60. Munro-Chadwick H: The oak and the thunder-god. J Anthropol Inst Gr Brit Ire 1900, 30:22-44.

61. Chidahakwa Z: Continuing the change: the role of dynamics of traditional institutions in the management of the Haroni and Rusitu forests in Chimanimani, Zimbabwe. CASS/PLAAS CBNRN 3rd Regional Workshop, 8-9.10.200I, Maputo, Mozambique .

62. Palmgrave WG: Narrative of the Year's Journey through Central and Eastern Arabia. ( $1862-63)$ London and Cambridge: MacMillan Co; 1865.

63. Wode B: Village forest protection regulation in Vietnam: strengthening participation in natural resources management. In Best Practices Using Indigenous Knowledge Edited by: Boven K, Morohashi J. Hague: Nuffic and UNESCO; 2002:I I 2- 129.

64. Himberg N: Community - based ecotourism as a sustainable development option in Taita Taveta, Kenya. In Taita Hills and Kenya Volume 40. Edited by: Pellika P, Ylhäisi J, Clarck B. Helsinki: Expedition Reports of the Department of Geography, University of Helsinki; 2004:87-95.

65. Serra $A$ : Legitimacy of local institutions of natural resources management: the case of M'Punga, Mozambique. In Mrena Researach Project, Working Paper No. 3, School of African and Asian Studies, Sussudenga Mozambique: University of Sussex and Centro de Experimentação Florestal; 200I.

66. Chanthitath K: Forest utilization by local people in Vang Vieng district. Forest Conservation and Afforestation Project (FPRCAP) [http:l /www.iges.or.jp/en/fc/phasel/ir98-3-25.pdf]. (Visited I.I0.06)

67. Laird SA: Forests, culture and conservation. In Cultural and Spiritual Values of Biodiversity Edited by: Posey DA. London: Intermediate Technology Publications and United Nations Environment Programme (UNEP); 1999:347-395.

68. Xu JC, Mikesell S: Indigenous knowledge of sustainable livelihood and resources governance in the MMSEA region. In Landscapes of Diversity: Proceedings of the III Symposium on MMSEA Edited by: Xu J, Mikesell S. Lijiang, China: Yunnan Sciences and Technology Press; 2002:3-22. 25-28.8.2002

69. Huabin H: Sacred natural sites in Xishuangbanna in southwestern China. In The Importance of Sacred Natural Sites for Biodiversity Conservation. International Workshop on the Importance of Sacred Natural Sites for Biodiversity Conservation. Kunming and Xishuangbanno Biosphere Reserve, China 17-20.2.2003 Edited by: Lee C, Schaaf T. UNESCO, MAB, CAS, IUCN; 2003:127-133.

70. Amirthalingam M: Folklore of sacred groves. Ind Folkl 2000, I:8-9. 
71. Rodgers WA: The sacred groves of Meghalaya. Man India 1994, 74:339-348

72. Khiewtam RS, Ramakrishnan PS: Socio-cultural studies of the sacred groves of Cherrapunji and adjoining areas in the North Eastern India. Man India 1989, 69:64-7I.

73. Apffle Marglin F, Mishra PC: Sacred groves: regeneration the body, the land, the community. In Global Ecology A New Arena of Political Conflict Edited by: Sachs W. London: Zed Books; 1993:I-39.

74. Patnaik S, Pandey A: Study of an indigenous community - based forest management system: Sarna (sacred grove). In Conserving the Sacred for Biodiversity Management Edited by: Ramakrishnan PS Saxena KG, Chandrasheekara UM. New Delhi and Calcutta: Oxford and IHB Publishing; | 998:3 |5-32 |

75. Bharucha E: Cultural and spiritual values related to the conservation of biodiversity in sacred groves of the western Ghat in Maharashtra. In Cultural and Spiritual Values of Biodiversity Edited by: Posey DA. Nairobi: United Nations Environment Programme; 1999:382-385.

76. Dudley A: Indigenous forest use practices and sustainability: a case of the Adivasis of the Nilgiri biosphere region, south India. In MA thesis Saint Mary's University, Halifax, Canada; 1999.

77. Hobley CW: Bantu Beliefs and Magic Frank Cass, London; 1967.

78. Zoundjihekpon J, Dossou-Glehouenou B: Cultural and spiritual values of biodiversity in West Africa: the case of Benin and Côte d'Ivoire. In Cultural and Spiritual Values of Biodiversity. A Complementary Contribution to the Global Biodiversity Assessment Edited by: Posey DA. London: Intermediate Technology Publications, UNEP; | $991: 70-37$.

79. Anoliefo GO, Isikhuemhen OS, Ochije NR: Environmental implications of the erosion of cultural taboo and practices in Awka - south local governmental arena of Anambra state, Nigeria: I. Forests, trees and water resources preservation. J Agric Env Ethics 2003, 16:281-296.

80. Falconer J: Non-timber forest products in southern Ghana: traditional and cultural forest values. In Cultural and Spiritual Values of Biodiversity Edited by: Posey DA. Nairobi: United Nations Environment Programme; 1999:366-370.

8I. O'Neal Campbell M: Sacred Groves for forest conservation in Ghana's coastal savannas: assessing ecological and social dimensions. Singapore J Trop Geo 2005, 26:151-169.

82. McWilliam A: Prospects for the sacred grove, valuing lulic forests on Timor. The Asian Pac J Anthropol 200I, 2:89-I I3.

83. Boven K, Morohashi J: Best Practices Using Indigenous Knowledge Nuffic: The Hague and UNESCO/MOST: Paris; 2002.

84. Hartland ES: Pin-wells and rag-bushes. Folklore I893, 4:45|-470.

85. De Gubernatis A: La Mythologie des plantes Paris: C. Reinwald; 1878.

86. Rix H: Tent and Teatament: A camping Tpour in Palestine Arno press New York (Original publication 1907); 1977.

87. Leyard AH: A Popular Account of Discoveries at Nineveh London: Murray; $|85|$.

88. Zwemer SM: The Influence of Animism in Islam London: MacMillan 1920.

89. Hasluck FW: Christianity and Islam under the Sultans Edited by: Hasluck MM. New York: Octagon Books; 1973.

90. Quantz JD: Dendro-psychosis. Amer J Psychol 1989, 9:447-506.

91. Yassin A, Akgul OGH, Ugur MS, Solak MH: The Monumental Tres of Manisa 1998. (In Turkish)

92. Thankappan-Nair P: Tree Symbols Worship among the Nairs of Kerala. In Tree Worship in India A New Survey of a Pattern of Folk-Religion Edited by: Gupta SN. Calcutta: Indian Publications; 1965:93-103.

93. Majupuria TC, Johshi DP: Religious and Useful Plants of Nepal and India Lashkar: Gupta M; 1997.

94. Gupta SM: Plant Myth and Traditions in India 3rd edition. Calcutta: Munshiram Manoharlal; 200I.

95. Blackman A: Some Egyptian and Nubian notes. Man 1910, 10:25-29.

96. Leland CG: Gypsy Sorcery and Fortune Telling London: T. Fisher Unwin; I89|.

97. Fergusson J: Tree and Serpent Worship Delhi \& Varanasi: Indological Book House; 197I.

98. Walhouse MJ: Rag-bushes and kindred observances. J Roy Anthropol Soc Gr Brit Ire 1880, 9:97-106.

99. McPherson JM: Primitive Beliefs in the Northeast of Scotland Kessinger Publishing (Electronic Edition); 2003.

100. Lucas AT: The sacred trees of Ireland. J Cork Hist Archaeol Soc 1968, 68:16-54.
101. Fletcher R: Scopelism. Amer Anthopol 1897, 10:201-214

102. Bar Tvi S, Abu Rabia A, Kressel GM: The charm of graves: Mourning Rituals and Tomb Worship among the Negev Bedouin Tel aviv: Ministry of Defence; 1998. (In Hebrew)

103. Upadhaya KD: Indian botanical folklore. Asian Folk Stu 1964, 23:15-34.

104. Wilson C: Peasant Life in the Holy Land. London: John Murray; 1906.

105. Morton A: Tree Heritage of Britain and Ireland Shrewsbury: Swan Hill Press; 1998

106. Shutova N: Trees in Udmurt religion. Antiquity 2006, 80:3 I8-327.

107. Groom N: Frankincense and Myrrh: A Stusy of the Arabian Incense London and New York: Longman; 198I.

108. Amar Z: The book of Incence Tel Aviv: Eretz; 2002. (In Hebrew)

109. Nielsen K: Incense in Ancient Israel Leiden: El Brill; 1986.

1 10. Dafni A, Lev E, Backmann S, Eichberger C: Ritual plants of Muslim graveyards in northern Israel. J Ethnobiol Ethnomedicine 2006, 2:38.

III. Weightham BA: Sacred landscapes and phenomenon of light. Geographical Review 1966, 86:59-71.

112. Ya'ari A: Jewish Travelers to Eretz Israel Tel Aviv: Gazit; 1946. (In Hebrew)

II3. Ginzburg MA: Dvir Vilna: Zemel; 184I. (In Hebrew)

114. Frazer JG: Magic and Religion London: Watts and Co; 1944.

I I5. Pandey BP: Sacred Plants of India: Plants of Human Kind Edited by: . New Delhi: Shree Publishing House; 1989.

116. Bechmann R: Tree and Man: The Forest in the middle Ages Edited by: . New York: Paragon House; 1990.

I 17. Frazer JG: Folklore in the Old Testament. Studies in comparative religion legend and Law London: MacMillan and Co; 1919.

I I8. Frazer JG: The Golden Bough: The Roots of Religion and Folklore. New York: Avenel Books; 1981.

1 19. Shelton AJ: Departure of the Nshie: a north Nsukka lbo origin legend. J Amer Folk 1965, 78: I I5-129.

120. Chien Y: Three types of Chinese deities-stone, tree and land. In PhD Thesis, Lancaster University; 1997.

121. Fleming P: A Journey through central Asia. Geog J 1936, 88:28-144.

122. Virtanen P: The role of customary institutions in the conservation of biodiversity: sacred forests in Mozambique. Environ Values 2002, I I:227-241.

123. Chouin G: Sacred grovesin history: pathways to social shaping of forest landscape in coastal Ghana. IDS Bull 2002, 33:39-46.

124. Horning NR: Explaining compliance with rules covering common-pool forest resource use and conservation: dynamics in Bara country, south western Madagascar. Meeting of the International Association for the Study of Common Property. Bloomington, Indiana: 1.5-4.6.2000

125. Harris WT: The Springs of Mende: Belief and Conduct Edited by: . Freetown: Sierra Leone University Press; 1968.

126. Posselt $F$ : The tree in the religious rituals of the Bantu of Southern Rhodesia. Man 1939, 39:126-127.

127. Mutoro HW: The Mijikenda Kaya as a sacred site. In Sacred Sites, Sacred Places Edited by: Carmichael DL, Hubert J, Reeves B, Schanche A. London: Routledge; 1994:132-138.

128. Firehead J, Leach M: Enriching the landscape: social history and management of transition ecology in the forest. Savanna mosaic of the Republic of Guinea. Africa: J Int African Ins 1996 , 66:14-36.

129. Stuart K, Ujiyediin C: Mongol tree worship. Archív Orientální 1997, 65:275-291.

130. Crooke W: The hill tribes of the central Indian hills. J Anthropol Inst Gr Brit Ire 1899, 8:220-248.

13I. Bhasin V: Religions and cultural perspectives of sacred sitesSitabari in Rajasthan. J Hum Ecol 1999, 10:329-340.

132. Foppes J, Ketphanh S: Forest extraction or cultivation? Local solution from Lao PDR Workshop on the Evolution and Sustainability of "Intermediate Systems" of Forest Management, FOREASIA, 28.6-1.7.2000 Lofoten, Norway.

133. Fowler CT: The ecological implications of ancestral religion and reciprocal exchange in a sacred forest in karendi (Sumba, Indonesia). Worldview 2003, 7:303-329.

134. Lyons AP: Three reverence amongst Papuans. Man 1923 , 23:72-73

135. Muddurooroo A: Aboriginal Mythology London: Thorsons; 1994. 
136. Yadin A: Tamuz Edited by: Broza M. Tel Aviv: Ministry of Defence; 1990. (In Hebrew)

137. Buchmann Y: Tree and market on the main road: Elon Be'Tsaa'ananim is Hanot Togarim. Teva Va'aretz 1988, 30:36-39. (In Hebrew)

138. Lebie AR, Freudenberger MS: Sacred groves in Africa: forest patches in transition. In Forest Patches in Tropical land Landscape Edited by: Schelhas J, Greenberg R. Washington: Island Press; 1966:300-324.

139. Crooke W: An Introduction to the Popular Religion and Folklore of Northern India Allahabad: Government Press; 1894.

140. Boulanger C: In the kingdom of Nataraja Madras: The South India Saiva Siddharta Works Publishing Society; 1993.

141. Akiba T: A study on Korean folkways. Folk Stu 16: I- 106.

142. Boomgaard P: Sacred trees and haunted forests - Indonesia, particularly Java, $19^{\text {th }}$ and $20^{\text {th }}$ centuries. In Asian Perceptions of Nature Edited by: Bruun O, Kallanda A. Nordic Institute of Asian Studies. Copenhagen: Curzon Press; 1995:39-53.

143. Samuels GB: Encounters with Trees, History and American Landscape New Brunswick, New Jersey: Rutgers University Press; 1999.

144. Curtiss SI: The ancient religion of Syria in centers of Moslem and Christian influence. Biblical World 1904, 23:326-338.

145. Curtiss SI: The local divinities of the Semites. Biblical World 1902, 19:288-299.

146. Ben Yosef S: Sacred graves in Judaea. Ariel 1996, II7I I 8: I I2-I 19. (In Hebrew)

147. Hilton-Sampson MW: Some Algerian supertitions noted among the Shawia Berbers of the Aures mountains and their nomad. Folklore 1915, 26:225-254.

148. Wanjohi GJ: An African conception of God: the case of the Gikuyu. J Relig Africa 1978, 9:|36-|46.

149. Gombya-Sembajjwe WS: Sacred forests in modern Ganda society. Uganda J 1995, 43:32-44.

150. Tate HR: Further notes on the Kikuyu tribe of British East Africa. J Roy Anthropol Soc Gr Brit Ire 1904, 34:255-265.

I5I. Wilson KB: Trees in fields in southern Zimbabwe. J South Afric Stud 1989, I5:369-383.

152. Mafu Hf: The I99I-92 Zimbabwean drought and some religios reactions. J Relig Afric 1995, 25:1991-92.

153. Rogers FH: Notes on some Madi-rain stones. Man 1927, 27:8I-87.

154. Halliday A: Annals of the House of Hanover Edited by: . Willims Sams: Lodon; 1826

155. Samatar SS: Somalia's horse that feed his master. In Afr Lang Cult Issue 3 Voice and Power: The Culture of Language in North-East Africa: Essays in Honour of BW Andrezejewski; 1996:I55-I70.

156. Drake C: The collision of traditions in Saikakus's Haikai. Harv J Asiatic Stud 1992, 52:5-75.

157. Johnson F: Some Bedouin customs. Man 19/8, 18:6-8.

158. Birge DE: Sacred groves in the ancient Greek World. In PhD. thesis University of California Berkley, Department of Ancient History and Archaeology; 1982.

159. Binbergen van $W$ : The land as body: an essay on the interpretation of ritual among the Manjaks of Guinea - Bissau. Medical Athropology Quarterly, New Series 1988, 2:386-40I.

160. Fulton RM: The political structure and functions of Poro in Kpelle society. Amer Anthrop 1972, 74:1218-1233.

16I. Masako T: Categories of Okinawa "ancestors" and the kinship syatem. Asian Folkl 1977, 36:31-64.

162. Evans A: Mycenaen tree and pillar cult and its Mediterranean relations. J Hellenistic Stud 1901, 2 I:99-204.

163. Porteous A: Forest Folklore, Mythology and Romance London: George Allen and Unwin Ltd; 1928.

164. Minniakhmetova T: Sacrificial rites of the Udmurts on the eastern land of the river Kama. Folklore 2001, I 7:107-II9.

165. Balzer MM: Rituals of gender identity: markers of Siberian Khanthy ethnicity, status and belief. Amer Athropo NS 198I, 83:850-867.

166. Wild RP: Funerary equipment from Agona - Swedru, Winnebah District, Gold Coast. I Roy Anthropol Gr Brit Ire 1937, 67:67-75.

167. Clifford M, Palmer R: A Nigerian chiefdom. J Roy Anthropol Soc Gr Brit Ire 1936, 66:393-435.

168. McGlasham N: Indigenous Kikuyu education. Afr Affairs 1964, 63:47-57.
169. Ambler $\mathrm{CH}$ : The renovation of custom in colonial Kenya: the 1932 generation succession ceremonies in Embu. J Afr Hist 1989, 30:139-156.

170. Crooke W: The cult of the Mother Goddesses in India. Folklore 1919, 30:292-308.

17I. Bunche RJ: The Irua ceremony among the Kikuyu of Kimbu district, Kenya. J of Negro Hist 194I, 26:46-65.

172. Hoffer CG: Mende and Sherbro women in high office. Can J Afr Stu 1972, 6:151-164. Special Issue: The Role of African Woman, Past Present and Future

173. M'Kenzie D: Children and Wells. Folklore 1907, 18:253-282.

174. Crooke W: The Dasahra: an autumn festival of the Hindus. Folklore 1915, 26:28-59.

175. Offiong DA: The functions of Ekpo society of the Ibidio of Nigeria. Afr Stu Rev 1984, 27:77-92.

176. Avivi S: The Druze in Israel and their Sacred Places. Jerusalem: Ariel (Ariel 142) 2000.

177. Zaharony I: Sacred families and magicians in the Gil'boa area. Ariel 1966, I I 7-I I 8:170-177.

178. Rouse WHD: Notes from Syria. Folklore 1895, 6: I72-175.

179. Godden GM: The sanctuary of Mourie. Folklore 1893, 4:498-508.

180. Soutter R, Ntiamoa-Baidu Y, Smith J, Rana D: Recognizing the contribution of sacred natural sites for biodiversity conservation. Lecture presented at the World Park Congress, Durban, South Africa; 2003.

18I. Talbot PA: The Bugunda of Lake Chad. J Anthro Inst Gr Brit Ire I9| I, 4 I :245-249.

182. Washburn-Hopkins E: Mythological aspects of trees and mountains in the great epic. J Amer Orient Soc 1910, 30:347-374.

183. Simoons FJ: Plant of Life, Plant of Death Madisson WI: University of Wisconsin Press; 1998.

184. Chandervaker P: Tree-cult in Saurashtra. In Tree Symbols in India, A New Survey of Pattern of Folk Religion Edited by: Sen Gupta S. Indian Folklore Series No. 5, Calcutta: Indian Publications; 1965:4 1-46.

185. Gebert E: Trees. Education about Asia 200I, 6:23-26.

186. Holtum DC: Some notes on Japanese tree worship. Transac Asiatic Soc. Japan, 2nd Series 1931, 89:1-19.

187. Randhawa MS: The Cult of Trees and Tree Worship in Buddhist-Ainu Scripture. New Delhi: Indian Fine Arts and Crafts Society; 1964.

188. Zarcone M: Stone people, tree people and animal people in Turkic Asia and Eastern Europe. Diogenes 2005, 207:35-46.

189. McConnell RE: Notes on the Lugwari tribe of Central Africa. J Roy Anthropol Inst Gr Brit Ire 1925, 55:439-467.

190. Frazer JD: Balder the Beautiful: the Fire Festivals of Europe and the Doc trine of the External Soul New York: McMillan; 1923.

191. Minnikhmetova T: Sacrificial rites of the Udmurts on the eastern bank of the river Kama. Folklore 200I, I 7:I07-19.

192. Furness WH: The ethnography of the Nagas of Eastern Assam. J Roy Anthropol Inst Gr Brit Ire 1902, 32:445-466.

193. Vilnay Z: Sepulchral Monuments in Israel HaRav Kook, Jerusalem; 1963. (In Hebrew)

194. Byers BA, Cunliffe RN, Hudak AT: Linking the conservation of culture and Nature: a case study of sacred forests in Zimbabwe. Hum Ecol 2001, 29:187-218.

195. Ranger T: Taking hold of the land: holy places and pilgrimage in twentieth-century Zimbabwe. Past Present 1987, I | 7:158-194.

196. Sigu GO, Omenda TT, Ongugo PO, Opiyo A: Sacred groves institutions, rule enforcement and impact on forest condition: the case of Ramogi Hill Forst Reserve, Kenya. (Draft no. 4. n.d.). 1987 [https://www.biodiv.org/doc/case-studies/for/cs-ecoforke-0l-en.pdf]. (Visited 9.4.07)

197. Millar D, Aniah R, Atoyure R: Shrines and Groves. COMPASS Newsletter 1999:34-36.

198. O'Neal-Campbell M: Traditional forest protection and woodlots in the coatal savannah of Chana. Environ Conserv 2004, I:225-232.

199. Mgumia FH, Oba G: Potential role of sacred groves in biodiversity in Tanzania. Environ Conserv 2003, 30:259-265.

200. Pliny P: Natural History Edited by: Rackham H. Loeb Classical Library. London and Cambridge (Massachusetts): Harvard University Press 1945. 